\title{
ИНСТИТУТ СУДЕБНОГО ПРИМИРЕНИЯ И ЕГО МЕСТО В СИСТЕМЕ АЛЬТЕРНАТИВНЫХ СПОСОБОВ УРЕГУЛИРОВАНИЯ СПОРОВ
}

\author{
(C) 2020 Губайдуллина Э.X. \\ кандидат юридических наук \\ Самарский государственный экономический университет, Россия, Самара \\ E-mail: elmira_zaripova@mail.ru
}

\begin{abstract}
В представленной статье рассматриваются актуальные вопросы новой примирительной процедуры - судебного примирения. Освящается его правовая сущность, принципы и правовое регулирование. Проводится сравнительный анализ судебного примирения с иными примирительными процедурами. Исходя из этого в работе выявлены достоинства и недостатки исследуемой процедуры, обозначены проблемные аспекты в ее применении на практике. Автор приходит к выводу о том, что сама идея привлечении профессиональных судей в разрешение споров в досудебном порядке достаточно интереса и перспективна, ею уже достаточно давно пользуются зарубежные государства, но на сегодняшний день, данная процедура все же требует более детального законодательного регулирования.
\end{abstract}

Ключевые слова: правовые конфликты, медиация, Верховный Суд РФ, судебное примирение, примиритель принципы.

На сегодняшний день можно констатировать, что в большинстве стран особое внимание уделяется совершенствованию способов и средств защиты нарушенных прав и законных интересов граждан и организации. И наряду с общепризнанным судебным способом наибольшую роль в решении данного вопроса отводится альтернативным методам решения правовых конфликтов.

Формирование особых юридических условий позволяющих урегулировать возникающие проблемные ситуации мирным способом, в России, в настоящий момент находится на начальной стадии, пока необходимые проекты реформ только разрабатываются и готовятся к внедрению в российскую правовую действительность. И нужно сказать, что это необходимый и достаточно важный шаг, который, как справедливо отметила К.Н.Горшкова, позволит не только оптимизировать судебную нагрузку, но и повысит качество правосудия, обеспечит надежные гарантии защиты граждан и организаций [10].

Конституция РФ гарантирует каждому судебную защиту его прав и свобод, но следует признать, что это далеко не единственный способ, который позволяет урегулировать возникающие спорные ситуации [1]. Так в РФ можно выделить следующие институты, которые позволяют разрешать конфликты в внесудебном порядке: медиация, третейские суды, Уполномоченный по правам человека в РФ, Уполномоченный по защите прав предпринимателей, Уполномоченный по правам ребенка [11]. Совместно данные институты призваны создать реально функционирующий механизм позволяющий представить достойную альтернативу судебному разбирательству, сократить время, затрачиваемое на решение споров.

К сожалению, приходится констатировать, что примирительные процедуры используются, к сожалению достаточно редко - так количество дел которые были завершены благодаря медиации составляет $0,008 \%$ от общих дел рассматриваемых в судах общей юрисдикции и 0,002\% от общего количества дел арбитражных судов [10]. Причинами, по которым данные способы «более мирного» разрешения правового конфликта, не пользуются большой популярностью, является отсутствие квалицированных специалистов, которые действительно могли бы оказать грамотную правовую и иную помощь в урегулировании спора, сложности при возбуждении исполнительного производства, обращении взыскания на имущество должника и при совершении иных действий связанных с восстановлением нарушенных прав.

Все это обусловило необходимость в совершенствовании сложившейся системы примирительных механизмов, выявить имеющиеся проблемы и разработать целый комплекс реаби- 
литационных мер, которые существенно повысят их качество и это позволит расширить круг их применения в правовой практике.

В связи с этим Пленумом Верховного Суда РФ (далее ВС РФ) было принято Постановление № 1 от 18.01.2018 г., на основе которого был подготовлен проект Ф3 № 421600-7 «О внесении изменений в отдельные законодательные акты РФ в связи с совершенствованием примирительных процедур» [7]. Данный законопроект, после долгих переработок был принят и ввел в Гражданский процессуальный кодекс, Арбитражный процессуальный кодекс и Кодекс административного судопроизводства, более обновленный перечень примирительных процедур, который включает в себя:

- переговоры;

- посредничество (включая медиацию);

- судебное примирение.

Особый интерес вызывает такая достаточно новая для российской действительности процедура судебное примирение, которое осуществляется при участии особого лица, судебного примирителя, которая может быть использована на любой стадии производства по делу. В целом оно предполагает право сторон на обращение уже в ходе рассматриваемого спора к судебному примирителю, и урегулировать имеющийся конфликт [11].

Судебный примиритель - это центральная фигура рассматриваемого действия, он не является участвующей стороной и соответственно не только не заинтересован в исходе дела, но и в связи с этим, он не имеет права совершать действия, которые повлекут за собой возникновение, изменение или прекращение прав и обязанностей у лиц участвующих в деле.

Новеллой отечественного законодательства стало закрепления положения о том, что выступать в указанном качестве могут только судьи пребывающее в отставке. В Постановлении IX Всероссийского съезда судей данному вопросу было уделено особое внимание и разъяснено, что в связи « с высокой социальной ролью судьи, его значимостью для государства и общества» необходимо возложить обязанности по исполнению новой примирительной процедуры именно на таких должностных лиц, пребывающих в отставке [9]. При назначении судьи важно учитывать причину его отставки, профессиональный опыт, длительность полномочий, его моральнонравственные качества, и возможность оказы- вать влияние на стороны в целях склонениях их к более мирному разрешению спора [12]. Таким образом, предполагается повысить качество примирительной процедуры, ее эффективность.

Для того, чтобы более подробно отрегулировать процесс совершения рассматриваемого действия, ВС РФ 31.10.2019 был утвержден Регламент проведения судебного примирения, который предусматривает установление организационных основ к самой процедуре и судьям, а также отдельные процессуальные моменты, связанные с ее проведением [8].

Целью судебного примирения является достижение спорящими сторонами приемлемого для каждого из них результата и разрешение конфликтной ситуации с учетом имеющихся интересов каждого из них. Данное положение не является специфическими и присущим только какому-то конкретному виду примирительной процедуры - это общая черта, лежащая в основе их правовой сущности и определяющая основное направление их деятельности.

Среди задач, которые возлагаются на новую примирительную процедуру, следует назвать сближение позиций сторон, определение возможностей для их сближения с учетом имеющихся интересов, предоставление дополнительных возможностей для урегулирования возникшего спора [8]. Это очень важные отправные ориентиры, которые позволяют выявить сущность данного правового явления и его социальное назначение.

Судебное примирение осуществляется при условии соблюдения следующих принципов: независимости, беспристрастности, добросовестности, конфиденциальности, добровольности, сотрудничество и равноправие. Если сравнивать изложенные принципы, с другими примирительными процедурами, например медиацией, то можно выявить определенное сходство. Порядок ее осуществления также базируется на соблюдении принципов добровольности, конфиденциальности, сотрудничества, равноправия, беспристрастности и независимости медиаторской деятельности [12].

Так, независимость и беспристрастность лица, осуществляющего медиацию или судебное примирение выступают основами данных процедур и предполагают отсутствие взаимозависимости, связанности между ними и участниками спора, отсутствие заинтересованности в разрешении конфликта в пользу одной из сто- 
рон, симпатий к кому-либо из них. Как отмечает Т.В.Летута, Федеральный закон от 27.07.2010 N 193-Ф3 «Об альтернативной процедуре урегулирования споров с участием посредника (процедуре медиации)», содержит в себе отдельные нормы защищающие действие указанных принципов. Так, ст.15 устанавливает запрет на осуществление медиатором его деятельности, в том случае если он имеет прямую заинтересованность в исходе спора или состоит с кем-то из сторон в родственных отношениях [5]. Также немаловажное значение стоит уделить действующему принципу добровольности, который означает, что все действия участники конфликта совершают без какого-либо принуждения, на основе собственного волеизъявления. И подписывая соглашение о медиации, стороны тем самым выражают и свое одобрение к тому лицу, которое является посредником между ними.

Добровольность, в контексте, судебного примирения имеет несколько иное значение. Так, несмотря на то, что по сути примирителя выбирают стороны, окончательно он утверждается только судом. Стороны существенно ограничены в выборе, поскольку кандидатура примирителя должна быть выбрана только из списка утвержденного Пленумом ВС РФ. Также судебный примиритель выполняет достаточно активную роль в ходе такой процедуры: он может вести переговоры, изучать не только документы, которые предоставляют участники, но и знакомится с материалами дела (с предварительного согласия суда), давать сторонами рекомендации по урегулированию спора.

Еще одним важным принципом является конфиденциальность. Ее сущность выражается в том, что процедура судебного примирения не может быть написана на-аудио, -видеоносители, иные материальные носители. Полученная примирителем, в ходе осуществления данного действия, информация не может распространяться среди третьих лиц [12]. Таким образом, обеспечивается защита не только персональных данных участвующих сторон, но и иные сведения которые являются значимыми для них, составляют коммерческую тайну.

Также применительно к судному примирению отдельно хочется упомянуть про принцип добросовестности. В настоящее время ему уделяется особое внимание, особенно в контексте регулирования хозяйственных правоотношений. Несмотря на то что «добросовестность» яв- ляется оценочной категорией, в основе которой лежат представления о надлежащем проявлении уважении к чужими правам и интересам, Пленум ВС РФ в своем постановлении от 23.06.2015 № 25 отметил, что судьи должны уделять особое внимание добросовестному поведению сторон спора [6]. И в связи с этим представляется очевидным, что и судебный примиритель в случае наличия каких-либо отклонений от него должен отказаться от осуществления процедуры.

Стоит отметить, что правовое регулирование новой примирительной процедуры, в отличие от уже имеющихся, должно было уделить гораздо больше внимания личности судебного медиатора, его образованию, опыту работы. В разработанном ВС РФ Постановлении № 1 от 18.01.2018 предполагалось, что будут внесены соответствующие корректировки в положения Закона РФ от 26.06.1992 № 3132-I «О статусе судей в Российской Федерации» и ФЗ от 14.03.2002 № 30-Ф3 «Об органах судейского сообщества в РФ», которые должны были определить, что судебным примирителем может быть судья в отставке, имеющий соответствующий опыт и квалификацию. Однако, после рассмотрения проекта данные нормы не были приняты, в более упрощенной форме они вошли утверждённый ВС РФ Регламент проведения судебного примирения. Но насколько это закономерно? Ведь требования к судьям и порядок их назначения на должность, предусмотрены специальными нормативными актами, в которых о таком институте как судебный примиритель ничего не сказано.

Вполне возможно, что это связано с тем, что судебный примиритель судьей как таковым не является, он не вершит правосудие, а только помогает сторонам выйти из конфликта более простым и мирным способом, найти компромисс друг с другом. И поэтому отражать в специальном законе профессиональные требования к такому лицу не имеет смысла, но было бы более целесообразным отразить его правовое положение и иные специфические особенности не Регламенте ВС РФ, а в отдельном федеральном законе, возможно даже объединенном с иными примирительными процедурами.

Это представляется возможным потому что, по сути, все примирительные процедуры взаимодополняют друг друга, позволяя обеспечить более комплексный подход в разрешении спора. Так, например, медиация являясь внесудебной 
примирительной процедурой, наряду с судебным примирением, образуют два отдельных этапа в разрешении спора, две возможности по-разному взглянуть на имеющуюся проблему. При этом никто не ограничивает стороны в выборе способа примирения - можно выбрать одну, а можно воспользоваться обеими поочередно. Они не заменяемы и дают сторонам больше возможностей в урегулировании конфликтов внутри своих правоотношений.

Изначально, в проекте будущего закона было запланировано, что роль судебного примирителя смогут выполнять не только судьи в отставке, но и работники аппарата суда, имеющие высшее юридическое образование и стаж работы по юридической специальности не менее пяти лет [10]. Однако, данное положение не было одобрено и утверждено, поскольку посчитали не целесообразным наделять работников суда такими полномочиями, в силу того, что все-таки они не обладают такими познаниями и возможностями для разрешения спора в соответствии с принципами независимости и беспристрастности, и к судьям у граждан доверия будет больше, нежели к иным лицам. Ведь процедура медиации особой популярностью не пользуется, и одной из причин является отсутствие уверенности в профессионализме медиатора.

Список судебных примирителей подлежит утверждению Пленумом ВС РФ исходя из предложений верховных судов республик, краевых, областных судов, судов городов федерального значения, суда автономной области, судов автономных округов, окружных (флотских) военных судов. Однако видится более логичным установить единый перечень судебных примирителей, отдельно для каждого субъекта РФ, а также произвести его разграничение на судебных примирителей, действующих в судах общей юрисдикции и арбитражных судов.

Возможные результаты судебного примирения закреплены в соответствующих статьях процессуального законодательства: ст. 153.7 ГПК РФ [3], ст. 138.6, ч. 3 ст. 190 АПК РФ [2], ст. 137.7 КАС РФ [4]. Их перечень примерно одинаковый и выглядит следующим образом: заключение мирового соглашения в отношении всех или части заявленных требований; частичный или полный отказ от иска; частичное или полное признание иска; полный или частичный отказ от апелляционной, кассационной жалобы, надзорной жалобы (представления); признание обстоятельств, на которых другая сторона основывает свои требования или возражения.

Однако, с учетом закрепления в качестве разновидности примирительных процедур медиации, целесообразно данные статьи дополнить и таким результатом процедур, как заключение медиативного соглашения, которое также подлежит утверждению судом. Это позволит в будущем на основе статистических данных отследить эффективность внесенных изменений в случае их утверждения.

Также судебный примиритель наделен полномочием прекратить проведение примирительной процедуры, если увидит что разрешение спора в досудебном порядке невозможно, если сами участники спора не соблюдают установленный порядок и принципы судебного примирения, неоднократно не являются на встречу с судебным примирителем, затягивают проведение судебного примирения, препятствуют деятельности судебного примирителя и иным способом затягивают рассмотрение дела. В любом из этих случаев судебный примиритель составляет мотивированный письменный отказ, который передает суду и сторонам. То есть мы опять можем наблюдать достаточно тесное взаимодействие между судом и фигурой примирителя.

Таким образом, можно отметить, что законодателем прикладываются усилия для того, чтобы повысит уровень эффективности примирительных процедур, и стимулировать участников споров к их активному применению. Появление судебного примирения стоит расценивать как новый этап в развитии альтернативных способов урегулирования споров. Насколько будет качественна и результативна его деятельность, покажет практика, но сама идея о привлечении профессиональных судей в разрешение споров в досудебном порядке достаточно интереса, и ею уже достаточно давно пользуются зарубежные государства, где медиация, в частности судебная, является востребованным институтом процессуального права. 


\section{Библиографический список}

1. Конституция Российской Федерации (принята всенародным голосованием 12.12.1993) (с учетом поправок, внесенных Законами РФ о поправках к Конституции РФ от 30.12.2008 N 6-ФКЗ, от 30.12.2008 N 7-ФКЗ, от 05.02.2014 N 2-ФКЗ, от 21.07.2014 N 11-ФКЗ) [Электронный ресурс].- Доступ из СПС «Консультант Плюс» (дата обращения: 14.03.2020).

2. Арбитражный процессуальный кодекс Российской Федерации от 24.07.2002 № 95-Ф3 (ред. от 02.12.2019) [Электронный ресурс].- Доступ из СПС «Консультант Плюс» (дата обращения: 14.03.2020).

3. Гражданский процессуальный кодекс Российской Федерации от 14.11.2002 № 138-Ф3 (ред. от 02.12.2019) [Электронный ресурс].- Доступ из СПС «Консультант Плюс» (дата обращения: 14.03.2020).

4. Кодекс административного судопроизводства Российской Федерации от 08.03.2015 № 21- Ф3 (ред. от 27.12.2019) [Электронный ресурс]. - Доступ из СПС «Консультант Плюс» (дата обращения: 14.03.2020).

5. Федеральный закон от 27.07.2010 № 193-Ф3 «Об альтернативной процедуре урегулирования споров с участием посредника (процедуре медиации) (последняя редакция) [Электронный ресурс].- Доступ из СПС «Консультант Плюс» (дата обращения: 14.03.2020).

6. Постановление Пленума Верховного Суда РФ от 23.06.2015 № 25 «О применении судами некоторых положений раздела I части первой Гражданского кодекса Российской Федерации» [Электронный ресурс].- Доступ из СПС «Консультант Плюс» (дата обращения: 14.03.2020).

7. Постановление Пленума Верховного Суда РФ от 18.01.2018 «О внесении изменений в Государственную Дума Федерального собрания Российской Федерации проекта федерального закона «О внесении изменений в отдельные законодательные акты Российской Федерации в связи с совершенствованием примирительных процедур» [Электронный ресурс].- Доступ из СПС «Консультант Плюс» (дата обращения: 14.03.2020).

8. Постановление Пленума Верховного Суда РФ от 31.10.2019 № 41 «Об утверждении Регламента проведения судебного примирения» [Электронный ресурс].- Доступ из СПС «Консультант Плюс» (дата обращения: 14.03.2020).

9. Постановление IX Всероссийского съезда судей от 08.12.2019 № 1 «Об основных итогах функционирования судебной системы Российской Федерации и приоритетных направлениях ее развития на современном этапе» [Электронный ресурс].- Доступ из СПС «Консультант Плюс» (дата обращения: 14.03.2020).

10. Горшкова К.Н., Желонкин С.С. Примирительные процедуры в России: новеллы процессуальной реформы в России: новеллы процессуальной реформы// Вестник Санкт-петербургского университета МВД России. 2019. № 1. С.124-129.

11. Изместьева E.M., Самохвалов Н.А. О возможных законодательных новеллах в рамках совершенствования примирительных процедур в Российской Федерации на современном этапе//Балтийский гуманитарный журнал. 2019. № 2. С.67-72.

12. Мищенко E.B., Летута Т.В. Принципы судебного примирения, медиации и арбитража: сравнительноправовой аспект//Российское право: Образование. Практика. Наука. 2019. № 2. С.90-95. 